\title{
ANALISIS PUTUSAN MAHKAMAH KONSTITUSI NO. 68/PUU/XII/2014 KAITANNYA DENGAN NIKAH BEDA AGAMA MENURUT HUKUM ISLAM DI INDONESIA
}

\author{
Islamiyati \\ Universitas Diponegoro, Semarang \\ e-mail: islamiyati@yahoo.co.id
}

\begin{abstract}
Background research originated from the Constitutional Court decision No. 68/PUU / XII /2014 rejected the application for judicial review of material (judicial review) Article 2 Paragraph (1) of the Constitution NRI UUP 1945. The goal is to analyze the legal considerations of the decision of the judge of the Constitutional Court No. 68/PUU/XII/2014 and its legal consequences. The judge rejected the applicant because it contradicts the principle of the Godhead, moral values, culture and principles of marriage law in Indonesia. The existence of Islamic law can be reestablished by the interpretation of Article 2 Paragraph (1) UUP properly and constitutionally. The role of the Constitutional Court decision has correlate between religion and state laws are harmonized, and can enforce Islamic law which is based on maqāsid al-sharīah.
\end{abstract}

[]

Latar belakang penelitian berawal dari putusan MK No. 68/PUU/XII/2014 yang menolak permohonan uji materiil (judicial review) Pasal 2 Ayat (1) UUP terhadap UUD1945. Tujuannya untuk menganalisis pertimbangan hukum putusan hakim MK No. 68/PUU/XII/2014 dan akibat hukumnya. Hakim menolak permohonan pemohon karena bertentangan dengan prinsip Ketuhanan, nilai moral, budaya dan prinsip hukum perkawinan di Indonesia. Eksistensi hukum Islam dapat ditegakkan kembali oleh penafsiran Pasal 2 Ayat (1) UUP secara benar dan konstitusional. Peran putusan MK telah mengkorelasikan antara hukum agama dan negara yang harmonis, serta dapat menegakkan hukum Islam yang berpijak pada maqāșid al-sharīah.

Keywords: Putusan MK No. 68/PUU/XII/2014; nikah beda agama; hukum Islam 
Islamiyati

\section{Pendahuluan}

Putusan Mahkamah Konstitusi No. 68/PUU/XII/2014 adalah putusan tentang penolakan uji materiil Pasal 2 Ayat (1) Undang-Undang Perkawinan No. 1/1974 (UUP No. 1/1974) terhadap Undang-Undang Dasar Negara Republik Indonesia 1945 (UUD 1945). Hakim menolak permohonan pemohon karena alasan yang digunakan pemohon bertentangan dengan landasan idiil Pancasila dan konstitusionil UUD 1945 Pasal 28E Ayat (1) dan (2), 29 Ayat (1) dan (2), 28J Ayat (2), 28B Ayat 1, 27 Ayat 1, 28D Ayat 1, dan 28 I Ayat2. ${ }^{1}$

Para pemohon mengajukan permohonan pengujian Pasal 2 Ayat (1) Undang-undang Perkawinan Nomor 1 Tahun 1974 (Selanjutnya ditulis UUP) karena adanya kesalahpahaman penafsiran Pasal 2 Ayat (1) UUP yang menyebabkan hak konstitusional warga negara terabaikan, maraknya penyelundupan hukum karena tidak ada legalitas nikah beda agama, dan perbedaan keabsahan perkawinan beda agama antara warga masyarakat dengan Pegawai Pencatat Nikah (PPN) dan tokoh masyarakat. Tujuan permohonan pengajuan tersebut untuk melegalkan nikah beda agama supaya pelakunya mendapatkan perlindungan hukum sehingga penyelundupan hukum nikah beda agama dapat dihindari. Selain itu, untuk mewujudkan HAM dan memenuhi hak konstitusional warga negara yang merasa dirugikan. Jadi yang menjadi fokus perhatian pada pengajuan permohonan uji materiil di atas adalah tentang keabsahan atau legalitas nikah beda agama, di mana hukum agama dan kepercayaan tidak membolehkannya.

Nikah beda agama adalah nikah yang dilaksanakan oleh dua pasangan yang berbeda keyakinan. Menurut UUP, nikah beda agama tidak dijelaskan secara tekstual, namun apabila dihubungkan dengan Pasal 2 Ayat (1) UUP, menjelaskan bahwa suatu perkawinan dapat dikatakan sah, jika perkawinan itu dilakukan menurut hukum masing-masing agama dan kepercayaannya itu. Dengan demikian sahnya perkawinan, tergantung dari hukum agama dan kepercayaan masing- masing pemeluknya, karena menurut hukum agama yang hidup di Indonesia, nikah beda agama dilarang dan mengharuskan untuk

\footnotetext{
${ }^{1}$ Kepaniteraan Mahkamah Konstitusi Republik Indonesia, Data Dokumen Putusan No. 68/PUUXII/2014, h. 6 .

158 || Volume 27, Nomor 2, Oktober 2017

AL-AHKAM p-ISSN: 0854-4603; e-ISSN: 2502-3209
} 
menikah yang satu keimanan. ${ }^{2}$ Nikah beda agama diperbolehkan apabila pasangan yang beda agama masuk ke agama salah satu pasangan, supaya pernikahan tersebut terpenuhi syarat dan rukunnya, sehingga dapat dicatatkan oleh negara agar mempunyai kepastian dan kekuatan hukum. ${ }^{3}$

Namun, pada zaman globalisasi seperti sekarang ini, banyak warga negara yang berkeinginan nikah beda agama tanpa penyamaan keimanan, karena menurut mereka (para pelaku nikah beda agama), aturan tentang nikah beda agama telah memaksa warga negara untuk keluar agama dan mengikuti agama pasangan, dan ini bertentangan dengan HAM. ${ }^{4}$ Para pelaku tersebut melakukan demikian, karena terjadi benturan hukum antara hukum perkawinan dengan keinginan mereka yang berpendapat bahwa menikah adalah hak asasi manusia (HAM).

Munculnya pelaku nikah beda agama yang tidak berdasarkan hukum agama, menunjukkan bahwa penafsiran Pasal 2 Ayat (1) UUP tidak konstitusional terhadap UUD 1945. Hal inilah yang menjadi argumentasi dasar dari warga negara yang merasa hak konstitusionalnya dirugikan untuk memohon kepada MK melakukan uji materiil Pasal 2 Ayat (1) UUP. Namun, hakim menolak permohonan tersebut dengan mengeluarkan putusan MK No. 68/PPU/XII/2016. Penolakan hakim MK untuk melakukan uji materiil Pasal 2 Ayat (1) UUP terhadap UUD NRI 1945 telah memunculkan pendapat pro dan kontra di masyarakat. Oleh karena itu sangatlah penting dilakukan penelitian tentang "Putusan Mahkamah Konstitusi No. 68/PUU/XII/2014 kaitannya dengan Nikah Beda Agama Menurut Hukum Islam". Adapun rumusan permasalahannya adalah "Bagaimanakah pertimbangan hukum putusan hakim MK No. 68/PUU/XII/2014 dan akibat hukumnya kaitannya dengan nikah beda agama dilihat dari perspektif hukum Islam? Peneliti membatasi dalam skup hukum Islam, supaya penelitian dapat terarah dan sistematis serta dapat mencapai tujuan penelitian.

2Muhammad Daud Ali, Hukum Islam dan Peradilan Agama (Kumpulan Tulisan) (Jakarta, Raja Grafindo Persada, 1997), h. 71. Lihat juga di Muhammad Daud Ali, Mimbar Hukum, No. 8, 1993, h. 76.

3Ibid,. h. 32.

${ }^{4}$ Kepaniteraan Mahkamah Konstitusi Republik Indonesia, Data Dokumen Putusan No. 68/PUUXII/2014, h. 6. 
Islamiyati

Penelitian ini berusaha mengkaji aturan yuridis nikah beda agama dan akibat hukumnya kemudian dikaitkan dengan produk peradilan yang berupa putusan hakim MK. Hal ini dilakukan melalui kajian pertimbangan hakim MK yang digunakan, termasuk dasar hukumnya, dengan cara menelaah materi atau substansi perundang-undangan yang mengatur tentang nikah beda agama. Terkait dengan tema tersebut, maka penelitian ini menggunakan pendekatan yuridis doktrinal. Yuridis artinya penelitian yang meneliti hal-hal yang menyangkut hukum, baik formil maupun informil,5 maksudnya adalah pendekatannya ditinjau dari sudut peraturan yang merupakan data sekunder, misalnya; UU Perkawinan No. 1/1974, PP No. 9/1975, KHI Inpres No. 1/1991. Doktrinal adalah penelitian yang menganalisis dokumen putusan MK No. 98/PUU/XII/2014. Spesifikasi penelitian ini adalah deskriptif analisis, maksudnya penelitian yang memberikan gambaran, menelaah, menjelaskan kemudian menganalisis putusan MK No. 98/PUU/XII/2014 dan dampak yuridisnya terhadap legalitas nikah beda agama.

Sumber data penelitian dibedakan menjadi bahan hukum primer dan sekunder, sedangkan metode pengumpulan data melalui metode dokumentasi. Data penelitian akan dianalisis secara kualitatif, dengan metode interpretasi/penafsiran hukum, karena metode analisis ini berfungsi untuk merekonstruksi gagasan yang tersembunyi di balik aturan hukum.

\section{Penentuan Hukum dan Hukum Perkawinan Beda Agama}

Putusan Hakim MK merupakan keputusan yang dikeluarkan oleh salah satu lembaga peradilan kaitannya dengan uji materiil terhadap pasal atau ayat perundang-undangan di Indonesia. Keputusan MK tersebut bersifat final dan terakhir terhadap keberadaan konstitusi yang diajukan kepadanya, berarti putusan MK tidak bisa diajukan banding.

Putusan MK kaitannya dengan uji materiil perundang-undangan ada tiga macam, yakni:6 Pertama, Putusan yang mengabulkan permohonan uji materiil UU terhadap UUD 1945, apabila produk UU tidak konstitusional terhadap UUD

\footnotetext{
5Soerjono Soekanto dan Sri Mamuji, Penelitian Hukum Normatif (Jakarta: Raja Grafindo Persada,1995), h. 7.

6Ibid., h. 290.
}

160 || Volume 27, Nomor 2, Oktober 2017

AL-AHKAM p-ISSN: 0854-4603; e-ISSN: 2502-3209 
1945. Artinya bertentangan dengan konstitusi atau tidak sesuai dengan cita hukum negara Indonesia, yakni Pancasila. Kedua, putusan yang menolak permohonan uji materiil UU terhadap UUD 1945, apabila produk UU konstitusional terhadap UUD 1945, artinya MK mempertimbangkan permohonan pemohon dengan mengundang pihak-pihak terkait untuk membuktikan dalil pemohon, setelah itu hakim berpendapat bahwa ternyata produk UU tidak sesuai dengan konstitusi negara yakni UUD 1945 dan Pancasila. Ketiga, putusan yang menyatakan tidak menerima permohonan, karena pemohon tidak memenuhi persyaratan untuk melakukan permohonan uji materiil.

Selain itu, peneliti menggunakan konsep penemuan hukum dan teori Stufenbau Han Kelsen serta teori maqāṣid al-sharīah yang dirumuskan oleh alShātibì.

Konsep penemuan hukum melalui interpretasi atau penafsiran dipergunakan, karena yang menjadi titik fokus permasalahan pada materi putusan MK No. 68/PUU/XII/2014 adalah tentang muatan materi Pasal 2 Ayat (1) UUP yang menimbulkan kesalahpahaman tentang pemberlakuan nikah beda agama. Oleh karena itu hakim MK berupaya menemukan hukum yang terkandung dalam Pasal 2 Ayat (1) UUP melalui penafsiran atau interpretasi hukum. Menurut Fitzgerald, sebagaimana dikutip oleh Sudikno, ${ }^{7}$ mengatakan bahwa interpretasi hukum secara umum ada 2 (dua) macam yaitu:

Pertama, interpretasi yang bersifat harfiah, yakni memahami hukum semata-mata merujuk pada kalimat di dalam peraturan, karena kalimat menjadi inti dan sekaligus pegangan di dalam memutuskan perkara. Kalimat yang merupakan litera legis menjadi patokan dasar untuk memutuskan perkara. Hal ini karena di dalam kalimat tersebut sudah mengandung pesan yang jelas, kalau dilakukan interpretasi lain akan menyebabkan kesalahan di dalam penerapan hukumnya.

Apabila dikorelasikan dengan Pasal 2 Ayat (1) UUP, cara memahaminya dengan menggunakan penafsiran harfiah atau gramatikal dari kalimat Pasal 2 Ayat (1) UUP yang menjelaskan bahwa sahnya suatu perkawinan tergantung dari hukum agama dan kepercayaan yang hidup dan diakui di Indonesia,

7Sudikno Mertokusumo, Penemuan Hukum Sebuah Pengantar (Yogyakarta: Liberty, 1996), h. 37. 
Islamiyati

seperti; Islam, Kristen, Katolik, Hindu, Budha dan Konghucu. Tidak ada perkawinan di luar hukum masing-masing agama dan kepercayaannya itu, berarti tidak ada perkawinan yang sah kecuali berdasarkan hukum agama.

Setiap perkawinan dinyatakan sah jika mekanisme, tata cara, aturannya sesuai dengan norma dan aturan agama yang diyakini dan dipercayai setiap warga negara. Oleh karena itu peran hukum agama sangat penting, karena hukum agama berkedudukan sebagai parameter atau tolak ukur tentang sahnya pernikahan. Apabila dalam hukum agama menyatakan sahnya suatu perkawinan, maka sah juga menurut hukum negara.

Kedua, interpretasi yang bersifat fungsional, artinya penafsiran yang tidak semata-mata mengikatkan diri pada kalimat yang menjadi acuan, tetapi lebih jauh mengusahakan pemahaman terhadap maksud yang sebenarnya dari dibuatnya peraturan tertentu. Teknisnya adalah dengan menggali, menghubungkan dan mensistematisasikan dengan sumber-sumber lain yang dinilai relevan sehingga dapat memberikan kejelasan lebih sempurna. Pemahaman terhadap apa yang terkandung di dalam klausula tentu tidak bisa hanya didasarkan kepada kalimat yang tersurat semata-mata, tetapi juga mesti dilakukan penggalian sehingga ditemukan apa yang tersirat di baliknya.

Interpretasi fungsional Pasal 2 Ayat (1) UUP kaitannya dengan nikah beda agama, dapat dijelaskan bahwa walaupun nikah beda agama tidak dijelaskan secara tekstual dalam UU Perkawinan. Namun apabila dipahami pasal yang lain, ternyata telah dijelaskan dalam Pasal 8 huruf (f) UUP. Rumusannya adalah "perkawinan dilarang antara dua orang yang mempunyai hubungan yang oleh agamanya atau peraturan yang berlaku dilarang kawin".

Nikah beda agama menurut ketentuan hukum agama yang hidup di Indonesia termasuk nikah yang dilarang atau tidak diperbolehkan sementara waktu karena belum terpenuhinya syarat perkawinan, apabila sudah terpenuhi syaratnya, maka sahlah nikah mereka, syarat tersebut adalah pasangan pelaku nikah agama harus sama agamanya. Garis hukumnya adalah nikah beda agama diperbolehkan apabila masing-masing pasangan mempunyai agama yang sama. Masing-masing agama pada hakekatnya menghendaki pernikahan dilaksanakan pada pasangan yang satu keimanan. ${ }^{8}$

8Ibid., h. 1-3.

162 || Volume 27, Nomor 2, Oktober 2017

AL-AHKAM p-ISSN: 0854-4603; e-ISSN: 2502-3209 
Penjelasan ini menegaskan bahwa tidak ada kekosongan hukum tentang peraturan nikah beda agama dalam UUP. Namun, sudah dijelaskan secara tersirat dalam Pasal 2 Ayat (1) dan Pasal 8 huruf (f) UUP melalui penafsiran fungsional atau konstekstual. Kedua pasal tersebut saling melengkapi dalam menjelaskan bahwa hukum agama juga diperlukan dalam pembangunan hukum perkawinan di Indonesia. Hal ini dikarenakan perjuangan dan bangunan bangsa Indonesia dibentuk berdasarkan aspek teologis, politis dan sosiologis sebagaimana terdapat dalam Alenia III UUD NRI 1945. Maksudnya, kedaulatan negara Indonesia didasarkan pada niat yang luhur agar berkehidupan, berkebangsaan yang bebas dan terhormat, berdasarkan nilai yang diajarkan oleh Allah Yang Maha Kuasa. Selain itu, juga sesuai dengan Sila I Pancasila yang dijabarkan lebih lanjut dalam Pasal 29 Ayat (1) dan (2) UUD NRI 1945.

Berdasarkan penjelasan di atas dapat disimpulkan bahwa cara memahami Pasal 2 Ayat (1) UUP adalah melalui penafsiran harfiah dan fungsional. Penafsiran harfiah menjelaskan bahwa sahnya suatu perkawinan tergantung dari hukum agama dan kepercayaan yang hidup dan diakui di Indonesia, seperti; Islam, Kristen, Katolik, Hindu, Budha dan Konghucu. Tidak ada perkawinan di luar hukum masing-masing agama dan kepercayaannya itu, berarti tidak ada perkawinan yang sah kecuali berdasarkan hukum agama. Penafsiran fungsional menjelaskan walaupun nikah beda agama tidak dijelaskan secara tekstual dalam UUP. Namun, ternyata telah dijelaskan dalam Pasal 8 huruf (f) UUP. Rumusannya adalah "perkawinan dilarang antara dua orang yang mempunyai hubungan yang oleh agamanya atau peraturan yang berlaku dilarang kawin". Nikah beda agama menurut ketentuan hukum agama yang hidup di Indonesia termasuk nikah yang dilarang sementara waktu (muaqqat).

Konsep pemberlakukan hukum larangan perkawinan nikah beda agama juga sesuai dengan Pancasila, yang berkedudukan sebagai cita hukum (Rechtsidee) tertinggi. Hal ini sesuai dengan teori Stufenbau Han Kelsen yang menjelaskan tentang jenjang tingkatan hukum tertinggi yang disebut ground norm atau basic norm. ${ }^{9}$

\footnotetext{
${ }^{9}$ Soejono Soekanto, Beberapa Permasalahan Hukum dalam Kerangka Pembangunan di Indonesia (Yogyakarta: UII Press, 1983), h. 35.
} 
Islamiyati

Putusan MK merupakan produk hukum atas perubahan sistem tata negara di Indonesia seiring dengan perkembangan demokrasi dan sistem konstitusi Indonesia. Peran putusan MK dapat ikut serta dalam penegakan dan penguat perundang-undang, oleh karena itu putusan MK mengandung nilai-nilai keadilan, kemanfaatan dan kebenaran. Menurut prinsipnya, hukum Islam menghargai adanya kemaslahatan dan kebaikan dalam setiap norma dan putusan hukum harus mengandung unsur kemaslahatan atau kebaikan.

Hukum Islam merupakan seperangkat peraturan yang berdasarkan wahyu Allah dan Sunnah Rasūl (Nabi Muhammad) tentang tingkah laku manusia mukallaf yang diakui dan diyakini berlaku dan mengikat semua umat yang beragama Islam. ${ }^{10}$ Hukum Islam berarti hukum yang mengikat orang Islam supaya taat dan patuh pada aturan hukumnya. Oleh karena itu, orang Islam harus menjalankan hukum Islam sebagai perwujudan ketaatannya, sehingga mendapatkan pahala dari Allah. Hukum Islam berdasarkan keyakinan akan adanya aturan Allah, dan bersifat universal, artinya nilai-nilai yang terkandung pada ajaran Islam berlaku untuk seluruh umat Islam karena dapat diterima oleh akal.

Kaitannya dengan nikah beda agama, yakni nikah yang dilangsungkan oleh seorang laki-laki dan seorang perempuan yang berbeda agama dan keyakinannya, menurut ajaran agama yang diakui di Indonesia (Islam, Kristen, Katolik, Hindu, Budha, Konghucu) tidak diperbolehkan atau tidak dianjurkan atau tidak sah. ${ }^{11}$ Hal ini disebabkan karena masing-masing agama menjelaskan bahwa pernikahan hendaklah dilakukan terhadap pasangan yang sama keyakinan/agamanya, artinya masing-masing agama mengajarkan supaya umatnya menikah dengan pasangan yang satu akidah/keimanan. ${ }^{12}$

Hukum Islam (pengikut Syafi'iyyah) telah menentukan bahwa nikah beda agama tidak dibolehkan, karena menyangkut akidah atau keimanan yang berbeda. Menurut keputusan Majlis Tarjih Muhammadiyah ke-22 di Malang Jawa Timur, pernikahan beda agama dalam segala bentuknya tidak diper-

10Mardani, Hukum Islam, Pengantar Ilmu Hukum Islam di Indonesia (Yogyakarta: Pustaka Pelajar, 2010), h. 14.

11Muhammad Daud Ali, Hukum Islam dan Peradilan Agama, h. 71.

12Ibid., h. 71.

164 || Volume 27, Nomor 2, Oktober 2017

AL-AHKAM

p-ISSN: 0854-4603; e-ISSN: 2502-3209 
bolehkan. ${ }^{13}$ Begitu juga menurut Fatwa MUI dalam Musyawarah Nasional ke II pada tanggal 26 Mei-1 Juni 1980 yang menetapkan bahwa nikah beda agama hukumnya haram, alasannya ${ }^{14}$ adalah: 1) al-Qur'an Surat al-Baqarah ayat 221 yang menjelaskan bahwa diharamkan laki-laki Muslim menikah dengan wanita musyrik sehingga mereka beriman. Selain itu juga menjelaskan bahwa diharamkan bagi wali menikahkan wanita yang berada di bawah tanggung jawabnya dengan laki-laki musyrik. 2) al-Qur'an Surat al-Mumtahanah ayat 10 yang menjelaskan, supaya laki-laki beriman tidak mempertahankan perkawinannya dengan wanita kafir, begitu juga wanita non Muslim supaya dikembalikan kepada laki-laki Muslim, karena perkawinan mereka diharamkan oleh Allah. 3) al-Qur'an Surat al-Tahrim ayat 6, yang memerintahkan supaya orang-orang beriman menjaga dan memelihara diri sendiri dan keluarganya dari api neraka. 4) Sabda Nabi Muhammad yang diriwayatkan oleh Imam al-Ṭabrānī yang mengajarkan bahwa nikah itu setengah dari ajaran agama, dan kita diperintahkan untuk hati-hati terhadap sisanya. 5) Sabda Nabi Muhammad yang diriwayatkan oleh Ibn al-Sura'i yang mengajarkan tentang pentingnya pengajaran pendidikan agama bagi orang tua kepada anaknya, karena orang tualah yang menjadikan anaknya Yahudi, Majusi, Nasrani dan Islam.

KHI menamakan perkawinan beda agama dengan sebutan perkawinan antar pemeluk agama. Pada Pasal 40 poin (c) KHI menyatakan bahwa dilarang melangsungkan pernikahan antara seorang pria dengan seorang wanita yang tidak beragama Islam. Pasal $44 \mathrm{KHI}$ menyatakan bahwa wanita Islam dilarang melangsungkan perkawinan dengan seorang pria yang tidak beragama Islam. Berdasarkan ketentuan Pasal 40 poin (c) dan $44 \mathrm{KHI}$ di atas memberikan pemahamkan bahwa garis hukum pernikahan beda agama menurut hukum perkawinan Islam adalah tidak boleh.

Menurut UU Perkawinan No. 1/1974 Pasal 2 Ayat (1) menjelaskan bahwa "Perkawinan adalah sah, apabila dilakukan menurut hukum masing-masing

\footnotetext{
13Pimpinan Wilayah Muhammadiyah Jawa Tengah, Dokumen Himpunan Putusan Majlis Tarjih Muhammadiyah 22 di Malang Jawa Timur, h. 8.

${ }^{14}$ H.A. Nasri Adlani ed. et.al,, Himpunan Fatwa Majlis Ulama Indonesia (Jakarta: MUI, 1997), h. 120122.
} 
Islamiyati

agamanya dan kepercayaannya itu". Walaupun persoalan pernikahan beda agama dalam UUP tersebut tidak dijelaskan secara tekstual. Namun, apabila dipahami pasal tersebut menjelaskan tentang peran hukum agama yang berkedudukan sebagai parameter atau tolok ukur tentang sahnya pernikahan, sehingga penentuan boleh tidaknya perkawinan tergantung dari hukum agama. Apabila dalam hukum agama menyatakan sahnya suatu perkawinan, maka sah juga menurut hukum negara.

Terkait dengan perkawinan beda agama, Nancy J. Smith-Hefner menyatakan bahwa pasangan yang menikah satu keimanan atau satu agama, maka rumah tangganya akan dilindungi oleh aturan yang seragam yang menjadi prinsip dasar dalam melaksanakan hak dan kewajiban masing-masing pasangannya. ${ }^{15}$ Mereka akan bersama-sama mengembangkan i'tikad baiknya dalam menempuh tujuan perkawinan, mengelola harta kekayaan, mendidik anak dan menyelesaikan sengketa hukum. Namun apabila mereka melakukan nikah beda agama, maka akan berakibat kompleks pada intern perkawinan itu sendiri dan pada masalah hukum lain, misalnya; hukum waris dan hak perwalian dalam pernikahan, serta hak asuh anak (haḍānah) ketika orang tua bercerai.

\section{Pertimbangan Hukum Putusan Hakim MK No. 68/PUU/XII/2014 Kaitannya dengan Nikah Beda Agama Dilihat dari Perspektif Hukum Islam}

Berdasarkan berkas putusan MK No. 68/PUU/XII/2014, hakim MK berpendapat bahwa para pemohon memang memiliki kedudukan hukum (legal standing) untuk mengajukan permohonan a quo. ${ }^{16}$ Namun, setelah MK me-

\footnotetext{
${ }^{15}$ Bahasa aslinya adalah "It's always a positive surprise because in Islam you are protected by the rules. There are clear rights and responsibilities for both husband and wife. Those are basic principles which have to be followed. In Islam you're not allowed to hurt each other. When we hurt another person, we have sinned. So if you marry within Islam, each partner supports the other and they grow in faith together." Lihat Nancy J. Smith-Hefner, "The New Muslim Romance: Changing Patterns of Courtship and Marriage Among Educated Javanese Youth", Journal of Southeast Asian Studies, Volume 36/Issue 03/October 2005, pp 441-459, Printed in the United Kingdom,The National University of Singapore Published online: 08 September 2005, h. 18.

16Lihat Pasal 5 PMK No. 6 Tahun 2005 tentang Pedoman Beracara dalam Perkara Pengujian Undang-Undang.
} 
meriksa permohonan pemohon, dan setelah meminta keterangan dari para pihak terkait, seperti; Presiden, Pimpinan Pusat MUI, Pengurus Besar Nahdlatul Ulama, Pimpinan Pusat Muhammadiyah, FPI, WALUBI, Presidium Dewan Rohaniawan Majelis Tinggi Agama Konghucu Indonesia (MATAKIN), Parisada Hindu Dharma Indonesia, Tim Advokasi Untuk Kebhinekaan, Persekutuan Gereja-Gereja di Indonesia (PGI), Konferensi Waligereja Indonesia (KWI), keterangan saksi dan ahli pemohon, maka hakim MK menyatakan bahwa permohonan pemohon bertentangan dengan Pancasila dan UUD NRI 1945. Hal ini berarti hakim menolak permohonan yudicial review Pasal 2 Ayat (1) UUP yang diajukan pemohon.

MK atas nama negara tetap merumuskan klausa Pasal 2 Ayat (1) UUP adalah "Perkawinan adalah sah, apabila dilakukan menurut hukum masingmasing agamanya dan kepercayaannya itu". Berarti keabsahan perkawinan menurut hukum perkawinan di Indonesia harus sesuai dengan hukum agama dan kepercayaan yang dipeluk oleh pasangan. Kaitannya dengan nikah beda agama, baru diperbolehkan atau disahkan apabila telah terjadi penyamaan agama atau keyakinan masing-masing pasangan.

Dasar pertimbangan hakim dalam menetapkan penolakan permohonan di atas adalah: 1) Pemohon menggunakan logika tafsir negatif dalam menafsirkan Pasal 2 Ayat (1) UUP, yakni membolehkan perkawinan tanpa mengikuti ajaran agama. Hal itu bertentangan dengan konstitusi negara, negara wajib melindungi dan menjaga jangan sampai terjadi pembebasan hukum perkawinan yang menghancurkan nilai-nilai dan kemurnian suatu agama. 2) Cara pandang pemohon keliru, karena menurut pemohon, perkawinan dipandang sebagai hukum keperdataan saja dan kebebasan yang melindungi HAM, tanpa memandang bahwa perkawinan adalah bagian terpenting dalam kehidupan yang seyogianya melibatkan hukum agama sebagai aturan hukumnya.

Upaya untuk menganalisis dasar pertimbangan hakim MK dalam menetapkan putusan No. 68/PUU/XII/2014 dalam perspektif hukum Islam, Hakim MK yang menolak permohonan pemohon sesuai dengan groundnorm yakni nilai-nilai yang terdapat dalam Pancasila, yakni Sila I tentang prinsip Ketuhanan. Selain itu, juga sesuai dengan amanat Alenia Keempat Pembukaan UUD NRI 1945 dan Pasal 29 Ayat (1) UUD NRI 1945 yang menerangkan bahwa negara Indonesia adalah negara yang berkedaulatan rakyat berdasarkan kepada Ketuhanan Yang Maha Esa. 
Islamiyati

Berdasarkan analisis di atas, penulis berpendapat bahwa putusan MK No. 68/PUU/XII/2016 yang menolak permohonan uji materiil Pasal 2 Ayat (1) UUP adalah keputusan yang tepat, karena ternyata Pasal 2 Ayat (1) UUP adalah selaras dan harmonis atau tidak bertentangan atau konstitusional dengan Pasal 28E Ayat (1) dan (2), 28I Ayat (1), 29 Ayat (2) UUD NRI 1945, 28B Ayat (1) UUD NRI 1945, 28D Ayat (1) UUD NRI 1945, 27 Ayat (1), 28D Ayat (1) dan 28I Ayat (2).

Lahirnya putusan MK berarti tujuan utama para pemohon untuk mengusulkan legitimasi hukum pada para pasangan yang melakukan nikah beda agama tanpa menyamakan keimanan atau agama para pasangan tidak diterima secara keseluruhan. Jadi, perkawinan beda agama berarti bertentangan dengan konstitusi negara Indonesia yang menempatkan Pancasila sebagai dasar hukum tertinggi, dan UUD NRI 1945 sebagai pengejawantahan nilai-nilai yang terkandung dalam Pancasila tersebut.

Teori maqāṣid al-shāri'ah yang dirumuskan oleh al-Shāțib̄̄,17 yang menjelaskan bahwa ada lima tujuan utama dalam hukum Islam, yakni: hifz al-dīn (menjaga agama), hifź al-nafs (menjaga jiwa), hifz al-'aql (menjaga akal), hifz̧ alnasl (menjaga kehormatan/keturunan), dan hifź al-māl (menjaga harta benda). Kaitannya dengan hukum pernikahan beda agama yang dilarang dalam hukum Islam, apabila dianalisis dengan teori al-Shātibī, dapat dijelaskan bahwa nikah beda agama tidak dapat menyelamatkan atau menjaga agama hifz al-dìn.

Hal ini disebabkan karena menurut ketentuan hukum perkawinan di Indonesia, nikah beda agama dapat disahkan apabila salah satu pasangan menundukkan diri dengan agama pasangannya atau menyamakan agama pasangannya. Berarti pelaku nikah beda agama harus meninggalkan agamanya demi sahnya perkawinan. Dengan demikian sangat dimungkinkan orang Islam meninggalkan agamanya demi sahnya pernikahan dengan pasangannya, dan sebaliknya.

Nikah beda agama juga bertentangan dengan tujuan hukum Islam yakni untuk memelihara kehormatan atau keturunan (hifz al-nasl). Biasanya hal ini

17al-Shātibī, al-Muwāfaqātfí Ușūl al-Aḥkām, Jilid II (tt: Dār al-Fikr, t.th.), h. 5. 
terjadi pada ketidakkonsekuenan atau ketidaktaatan pada hukum agama, seperti pasangan yang menikah dengan cara Islam, di mana pasangan yang beragama non Islam tersebut telah masuk Islam. Namun, setelah menikah pasangan tersebut kemudian pindah ke agama semula, sehingga pernikahannya dapat dibatalkan oleh hakim, apabila ada permohonan pembatalan pernikahan, apabila tidak ada permohonan, maka pernikahan tersebut dianggap masih bisa dilangsungkan. Jika hal itu dilihat dari perspektif hukum Islam normatif, hal itu termasuk perbuatan zina dan tentunya merusak kehormatan atau keturunan.

Pasangan yang menikah satu keimanan atau satu agama, maka rumah tangganya akan dilindungi oleh aturan yang seragam yang menjadi prinsip dasar dalam melaksanakan hak dan kewajiban masing-masing pasangannya. Sebaliknya, pasangan yang menikah beda agama, diprediksikan tidak akan dapat mengembangkan iktikad baiknya dalam keluarga karena terjadi perbedaan prinsip keyakinan, sehingga akan terjadi banyak konflik, misalnya; konflik antar pasangan, pendidikan anak, harta bersama, antara saudara suami dan istri, serta antara mertua dan menantu. Apabila terjadi distoleransi, maka memunculkan sengketa perkawinan yang berakhir pada perceraian. Perkawinan yang satu agama saja sering terjadi konflik, apalagi yang berbeda agama. Oleh karena itulah diperlukan upaya untuk menghilangkan konflik yang dapat merusak hubungan keluarga. Hal ini sesuai dengan kaidah fiqhiyyah yang menjelaskan bahwa "Kerusakan itu harus dihilangkan".18

\section{Akibat Hukum Putusan Hakim MK No. 68/PUU/XII/2014 Kaitannya dengan Nikah Beda Agama Dilihat dari Perspektif Hukum Islam}

Putusan hakim MK No. 68/PUU/XII/2014 adalah putusan final yang tidak bisa diupayakan banding, karena putusan $\mathrm{MK}$ adalah putusan yang pertama dan terakhir dalam menetapkan permohonan pengajuan uji materiil Pasal 2 Ayat (1) UUP terhadap UUD NRI $1945 .{ }^{19}$ Dengan demikian putusan MK tersebut sangat kuat, karena tidak bisa dibatalkan, kecuali ada permohonan untuk melakukan uji materiil yang diselesaikan melalui hukum acara

${ }^{18}$ Ahmad Sudirman Abbas, Sejarah Qawāild Fiqhiyyah (Jakarta: Pedoman Ilmu Jaya, 2004), h. 35.

${ }^{19}$ Lihat Pasal 10 Ayat 1 (a) UU No. 23/2004. 
Islamiyati

Pengujian Undang-Undang. Maka, sangatlah tepat apabila dalam proses persidangan MK memanggil pejabat negara, para pihak yang terkait seperti; pimpinan organisasi keagamaan Islam, Kristen, Katolik, Hindu, Budha dan Konghucu, keterangan ahli dan keterangan saksi, untuk diminta keterangan dan pendapatnya demi menghasilkan putusan yang adil dan benar. ${ }^{20}$

Eksistensi putusan MK 68/PUU/XII/2014 dapat berkedudukan sebagai yurisprudensi, karena hakim MK adalah hakim tinggi dalam pengujian materiil Pasal 2 Ayat (1) UUP. Akibat hukum putusan MK 68/PUU/XII/2014 adalah dapat digunakan sebagai salah satu sumber hukum pada dasar pertimbangan hukum hakim peradilan untuk menyelesaikan kasus nikah beda agama. Hal ini dikarenakan, putusan hakim MK 68/PUU/XII/2014 mampu menampilkan kekuatan berikut penjelasan dari Pasal 2 Ayat (1) UUP.

Berdasarkan hasil penelitian menjelaskan bahwa akibat putusan MK No. 68/PUU/XII/2014 adalah sebagai penguatan hukum agama untuk menjadi barometer dalam menentukan sah atau tidaknya perkawinan, termasuk tidak sahnya pernikahan beda agama karena melanggar konstitusi negara. Selain itu, putusan MK No. 68/PUU/XII/2014 telah mengarahkan dan memberikan petunjuk tentang penafsiran Pasal 1 Ayat (2) UUP secara benar, adil dan sesuai dengan ilmu hukum tentang bagaimana membaca, memahami dan menafsirkan pasal dan ayat dalam suatu perundang-undangan. ${ }^{21}$

Eksisitensi putusan MK No. 68/PUU/XII/2014 68/PUU/XII/2014 terhadap aturan hukum perkawinan Islam di Indonesia adalah:22 1) Dapat digunakan sebagai salah satu sumber hukum pada dasar pertimbangan hukum hakim untuk menyelesaikan kasus nikah beda agama. 2) Mampu menampilkan kekuatan berikut penjelasan dari Pasal 2 Ayat (1) UUP yang mengalami disfungsi karena kesalahpahaman dalam penafsiran. 3) Penguatan hukum agama untuk menjadi barometer dalam menentukan sah atau tidaknya perkawinan, termasuk tidak sahnya pernikahan beda agama karena melanggar konstitusi negara. 4) Telah mengarahkan dan memberikan petunjuk

${ }^{20}$ Lihat Pasal 1011 UU No. 23/2004.

21Islamiyat, "Implikasi Yuridis Putusan Mahkamah Konstitusi No. 68/PUU/XII/2014 Terhadap Penyelundupan Hukum Nikah Beda Agama dalam Perspektif Hukum Islam", Tesis, MIH UNDIP, Semarang, 2016, h. 234.

22Ibid., h. 236.

170|| Volume 27, Nomor 2, Oktober 2017

AL-AHKAM p-ISSN: 0854-4603; e-ISSN: 2502-3209 
tentang penafsiran Pasal 1 Ayat (2) UUP secara benar, adil dan sesuai dengan ilmu hukum tentang bagaimana membaca, memahami dan menafsirkan pasal dan ayat dalam suatu perundang-undangan. 5) Pelarangan penyelundupan hukum nikah beda agama, karena perbuatan tersebut tidak konstitusional atau melanggar Pasal 2 Ayat (1) UUP dan konstitusi negara yang dijelaskan dalam UUD NRI 1945.

Berdasarkan penjelasan di atas dapat diketahui bahwa Putusan MK No. 68/PUU/XII/2014 yang menolak permohonan uji materiil (judicial review) Pasal 2 Ayat (1) UUP berimplikasi yuridis terhadap pembaruan hukum Islam, yakni putusan MK:23 1) Dapat menegakkan kembali fungsi hukum agama Islam yang mengalami disfungsi dari penafsiran Pasal 2 Ayat (1) UUP yang tidak benar. 2) Dapat menciptakan kepastian dan ketertiban hukum serta memberi perlindungan dan pelayanan hukum yang berkeadilan pada dasar hukum perkawinan beda agama. 3) Mencegah adanya penyelundupan hukum nikah beda agama yang dilakukan oleh warga negara sehingga hukum perkawinan dapat ditegakkan secara keseluruhan. 4) Dapat mengkorelasikan hubungan hukum antara hukum agama dan negara yang harmonis. Negara Indonesia adalah negara yang Berketuhanan Yang Maha Esa, artinya negara yang mengakui dan melaksanakan ajaran Tuhan yang terdapat dalam agama yang diakui di Indonesia. Akibatnya, segala hukum yang ditetapkan oleh negara, tidak boleh bertentangan dengan prinsip-prinsip hukum agama. 5) Dapat reformulasikan hukum agama (Islam) yang berpijak pada prinsipprinsip dasar syari'ah Islam. Hal ini dilakukan oleh hakim dengan menggunakan dasar pertimbangan hukum yang tidak terpaku pada doktrin dan norma hukum perundang-undangan saja, melainkan harus dinamis demi mempertahankan esensi syariah Islam dan menegakkan keadilan. Bagi hakim menegakkan keadilan adalah lebih utama atau lebih penting daripada teks hukum. 6) Dapat menegakkan ruh keadilan sebagai cita hukum maqāsisid shari’ah. Hal ini dilakukan oleh hakim dengan menggunakan dasar pertimbangan hukum yang hidup di masyarakat seperti hukum agama. Sehingga putusan hakim dapat mewujudkan keadilan yang sesuai dengan perasaan masyarakat.

${ }^{23}$ A. Mukti Arto, Pembaruan Hukum Islam Melalui Putusan Hakim (Yogyakarta: Pustaka Pelajar, 2015), h. 9-10. 
Islamiyati

Peranan putusan MK No. 68/PUU/XII/2014 yang menolak permohonan uji materiil (yudicial review) Pasal 2 Ayat (1) UUP dalam pembangunan hukum Islam adalah dapat menguatkan eksistensi hukum agama sebagai tolak ukur penetapan sahnya perkawinan. Kaitannya dengan nikah beda agama, berarti nikah beda agama yang sesuai dengan hukum agamalah yang diakui oleh negara, sehingga mendapatkan perlindungan dan kepastian hukum. ${ }^{24}$

Penegakan hukum nikah beda agama sebetulnya ada pada PPN, PPN dapat menikahkan pasangan yang sebelumnya beda agama setelah ada penyamaan agama dari pasangan yang dibuktikan dengan KTP, dan sudah terpenuhi syarat dan rukunnya. Apabila di tengah perjalanan waktu pernikahan, salah seorang pasangan pindah ke agama semula, maka hal itu dapat menjadi permasalahan hukum apabila ada permohonan dari pihak yang mempunyai hak mengajukan permohonan, berupaya mengajukan permohonan pembatalan pernikahan ke hakim PA.

Setelah PA memeriksa dengan hukum acara singkat, terdapat bukti yang menunjukkan bahwa pelaku pernikahan melanggar syarat pernikahan, maka hakim berwenang membatalkan pernikahan tersebut. Perkawinan menjadi batal setelah ada keputusan pengadilan yang mempunyai kekuatan hukum tetap. Apabila tidak ada pihak yang mengajukan permohonan pembatalan pernikahan, maka menurut hukum positif di Indonesia, baik UUP maupun KHI, menghukumi bahwa pernikahan tersebut dapat berjalan, berarti sah dilakukan.

Padahal menurut hukum Islam normatif yakni hukum Islam yang berdasarkan wahyu Allah yakni al-Qur'ān, al-Hadith dan beberapa kitab fiqh menjelaskan bahwa perkawinan tersebut di mata Allah telah rusak dan pelakunya dianggap berbuat zina karena melakukan perkawinan yang tidak sah sebab tidak terpenuhi syaratnya, yakni calon suami dan istri harus beragama Islam. Akibat hukumnya adalah nikah tersebut tidak sah dan batal demi hukum. ${ }^{25}$ Hukum perkawinan lintas agama menurut empat mazhab, disini akan diuraikan pendapat-pendapat tersebut. Sebagaimana diuraikan

\footnotetext{
24Islamiyati, "Implikasi Yuridis Putusan Mahkamah Konstitusi No. 68/PUU/XII/2014", h. 236.

${ }^{25}$ Abdul Aziz Muhammad Azzam dan Abdul Wahhab Sayyed Hawwas, Fiqh Munakahat Khitbah, Nikah dan Talak (Jakarta: Amzah, 2011), h. 135.
} 
pada pembahasan terdahulu, bahwa hukum perkawinan antara seorang perempuan yang beragama Islam dengan seorang laki-laki non-Muslim, apakah ahl al-kitāb ataukah musyrik, maka jumhur ulama sepakat menyatakan hukum perkawinan tersebut haram, tidak sah. Akan tetapi apabila perkawinan tersebut antara seorang laki-laki Muslim dengan wanita non-Muslim baik ahl al-kitāb atau musyrik, maka para ulama berbeda pendapat mengenai siapa yang disebut perempuan musyrik dan ahl al-kitāb tersebut.26

Iman Abu Ḥanifah berpendapat bahwa perkawinan antara pria Muslim dengan wanita musyrik hukumnya adalah mutlak haram, tetapi membolehkan pria Muslim mengawini wanita ahl al-kitāb (Yahudi dan Nasrani), sekalipun ahl al-kitāb tersebut meyakini trinitas, karena menurut mereka yang terpenting adalah ahl al-kitāb tersebut memiliki kitab samawi.

Menurut mazhab ini yang dimaksud dengan ahl al-kitab adalah siapa saja yang mempercayai seorang Nabi dan kitab yang pernah diturunkan Allah, termasuk juga orang yang percaya kepada Nabi Ibrahim dan Suhufnya dan orang yang percaya kepada Nabi Musa dan kitab Taurat, maka wanitanya boleh dikawini. Bahkan menurut mazhab ini mengawini wanita ahl al-kitāb dhimmi atau wanita kitābiyah yang ada di Dār al-Harbi adalah boleh, hanya saja menurut mazhab ini, perkawinan dengan wanita kitābiyah yang ada di dārul harbi hukumnya makrūh tahrīm, karena akan membuka pintu fitnah, dan mengandung mafāsid yang besar, sedangkan perkawinan dengan wanita ahl al-kitāb dhimmi hukumnya makrūh tanzīh, alasan mereka adalah karena wanita ahl al-kitab dhimmi ini menghalalkan minuman arak dan menghalalkan daging babi.

Mazhab Maliki tentang hukum perkawinan lintas agama ini mempunyai dua pendapat yaitu: pertama, nikah dengan kitäbiyah hukumnya makruh mutlak baik dhimmiyah (wanita-wanita non Muslim yang berada di wilayah atau negeri yang tunduk pada hukum Islam) maupun harbiyah, namun makruh menikahi wanita harbiyah lebih besar. Akan tetapi jika dikhawatirkan bahwa si istri yang kitäbiyah ini akan mempengaruhi anak-anaknya dan meninggalkan agama ayahnya, maka hukumnya haram. Kedua, tidak makruh

\footnotetext{
${ }^{26}$ Mun'im A. Sirry (ed.), Fiqih Lintas Agama; Membangun Masyarakat Inklusif-Pluralis (Jakarta: Paramadina, 2004), h. 69-70.
} 
Islamiyati

mutlak karena ayat tersebut tidak melarang secara mutlak. Metodologi berpikir mazhab Maliki ini menggunakan pendektan sad al-dharīah (menutup jalan yang mengarah kepada kemafsadatan). Jika dikhawatirkan kemafsadatan yang akan muncul dalam perkawinan beda agama, maka diharamkan.

Demikian halnya dengan mazhab Syafi'i, juga berpendapat bahwa boleh menikahi wanita ahl al-kitāb, dan yang termasuk golongan wanita ahl al-kitāb menurut mazhab Syafi'i adalah wanita-wanita Yahudi dan Nasrani keturunan orang-orang bangsa Israel dan tidak termasuk bangsa lainnya, sekalipun termasuk penganut Yahudi dan Nasrani. Alasan yang dikemukakan mazhab ini adalah karena Nabi Musa dan Nabi Isa hanya diutus untuk bangsa Israel, dan bukan bangsa lainnya.

Pada mazhab Hanbali mengenai kajiannya tentang perkawinan beda agama ini, mengemukakan bahwa haram menikahi wanita-wanita musyrik, dan boleh menikahi wanita Yahudi dan Narani. Kelompok ini dalam kaitan masalah perkawinan beda agama tersebut banyak mendukung pendapat gurunya yaitu Imam Syafi'i. Tetapi tidak membatasi bahwa yang termasuk ahl al-kitāb adalah Yahudi dan Nasrani dari Bangsa Israel saja, tapi menyatakan bahwa wanitawanita yang menganut Yahudi dan Nasrani sejak saat Nabi Muhammad belum diutus menjadi Rasul. Solusinya adalah perkawinan tersebut harus diperbaharui dengan memenuhi syaratnya supaya sah di mata Allah.

Hukum nikah beda agama menurut hukum agama tidak boleh dilaksanakan, karena akan berakibat kompleks pada beberapa hal, antara lain:

Pertama, berpengaruh pada hukum waris mewarisi antara pewaris dan ahli waris. Apabila terjadi nikah beda agama, maka antara anak dan orang tua sebagai pewaris atau ahli waris, keduanya tidak berlaku hukum waris mewarisi karena tidak memenuhi syarat hukum waris Islam. ${ }^{27}$ Jadi, ahli waris yang beda agama ketika pewaris meninggal dunia, maka akan menjadi penghalang ahli waris tersebut untuk menerima harta warisan.

Dasar hukum perbedaan agama antara pewaris dan ahli waris yang non Islam, yang menjadi penghalang untuk saling mewarisi adalah hadis riwayat Bukhari dan Muslim yang artinya "Orang Islam tidak berhak mewarisi harta

27Ahmad Azhar Basyir, Hukum Waris Islam (Yogyakarta: UII Press, 2009), h. 94. 
orang kafir, dan orang kafir tidak berhak mewarisi harta orang Islam" (HR. Bukhāri dan Muslim). ${ }^{28}$ Juga terdapat dalam Hadith yang diriwayatkan oleh yang artinya "Tidak dapat saling mewarisi antara dua orang pemeluk agama yang berbeda" (HR. Așhāb al-Sunan). ${ }^{29}$

Kedua, berpengaruh pada hukum perkawinan Islam, pada masalah wali nikah dari mempelai perempuan. Wali mempunyai kewajiban untuk menikahkan anak perempuannya kepada laki-laki yang dikehendakinya. Salah satu syarat wali adalah beragama Islam, apabila terjadi perbedaan agama antara anak perempuan dan walinya, tentunya menjadi penghalang untuk melangsungkan pernikahannya. ${ }^{30}$

Ketiga, berpengaruh pada hukum perkawinan pada hak asuh anak (hadānah) ketika orang tua bercerai. Apabila terjadi perceraian dan usia anak di bawah 12 tahun, maka hak asuh anaknya ada di tangan ibunya, sedangkan biaya nafkah, pendidikan dan kesehatan ada di tangan ayahnya, semua itu dilakukan karena kepentingan anak. Namun, apabila ibunya tidak Muslim, maka tidak berhak haḍānah karena kekafirannya. Sebab hak haḍānah meliputi pendidikan agama pada anak tersebut.

\section{Kesimpulan}

Penelitian tentang putusan MK No. 68/PUU/XII/2014 kaitannya dengan nikah beda agama menurut hukum Islam dapat disimpulkan sebagai berikut: Pertama, MK sebagai salah satu lembaga negara yang berwenang melakukan hak uji materiil UU terhadap UUD NRI 1945 menetapkan menolak permohonan pemohon untuk melakukan uji materiil (yudicial review) Pasal 2 Ayat (1) UUP terhadap UUD NRI 1945, alasannya adalah bahwa dalil pemohon bertentangan dengan prinsip Ketuhanan sebagaimana diamatkan dalam Alinea Keempat Pembukaan UUD NRI 1945 dan Pasal 29 Ayat (1) UUD NRI 1945. Selain itu, dalil pemohon dalam menafsirkan Pasal 2 Ayat (1) UUP, juga bertentangan dengan nilai-nilai moral, agama, dan budaya yang hidup di Indonesia serta prinsip atau asas hukum perkawinan. Penolakan permohonan uji materiil (yudicial review) Pasal 2 Ayat 1 UU Perkawinan, berarti MK atas

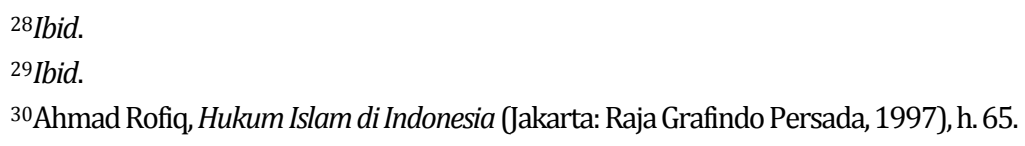


Islamiyati

nama negara tetap merumuskan bahwa klausa Pasal 2 Ayat (1) UUP adalah "Perkawinan adalah sah, apabila dilakukan menurut hukum masing-masing agamanya dan kepercayaannya itu". Dasarnya adalah bahwa Pasal 2 Ayat (1) UUP adalah tidak bertentangan dengan Pasal 28 E Ayat (1) dan (2), 28 I Ayat (1), 29 Ayat (2) UUD NRI 1945, 28 B Ayat (1) UUD NRI 1945, 28 D Ayat (1) UUD NRI 1945, 27 Ayat (1), 28 D Ayat (1) dan 28 I Ayat (2). Lahirnya keputusan MK berarti tujuan utama para pemohon untuk mengusulkan legitimasi hukum nikah beda agama tidak tercapai. Dilihat dari perspektif hukum Islam menjelaskan bahwa dasar pertimbangan hukum hakim MK adalah tidak terpaku pada doktrin dan norma hukum perundang-undangan saja, namun hakim juga menggunakan dasar pertimbangan hukum yang hidup di masyarakat seperti hukum agama. Sehingga dasar pertimbangan hukum hakim MK juga dapat menegakkan ruh keadilan sebagai cita hukum maqāṣid sharīah.

Kedua, akibat hukum putusan MK No. 68/PUU/XII/2014 terhadap hukum nikah beda agama dalam perspektif hukum Islam adalah bahwa putusan $\mathrm{MK}$ No. 68/PUU/XII/2014 menjadi dasar yuridis bahwa nikah beda agama tidak diperbolehkan oleh hukum agama (Islam) dan negara. Eksistensi hukum Islam dapat ditegakkan dan dikuatkan kembali oleh penafsiran Pasal 2 Ayat (1) UUP secara benar dan konstitusional. Putusan MK No. 68/PUU/XII/2014 telah mampu mengkorelasikan hubungan hukum antara hukum agama dan negara yang harmonis, serta dapat mereformulasikan hukum agama (Islam) yang berpijak pada prinsip-prinsip dasar syariah Islam yang menegakkan maqāșid sharïah (tujuan pembentukan hukum Islam).

Berdasarkan kesimpulan di atas, maka saran yang layak disampaikan adalah: Pertama, upaya pembentukan hukum perkawinan di Indonesia hendaknya diselaraskan dengan nilai-nilai moral, agama, dan budaya yang hidup di Indonesia serta prinsip atau asas hukum perkawinan, supaya sesuai dengan tujuan awal para pendiri bangsa Indonesia dan konstitusi negara. Hendaknya para pasangan yang akan menikah, taat pada hukum agama masing-masing serta menjunjung tinggi sikap toleransi. Kedua, hendaknya masyarakat mempunyai kesadaran untuk menegakkan hukum perkawinan dengan tidak melakukan nikah beda agama, karena akan mempengaruhi efektifitas hukum di masyarakat. Begitu juga apabila masyarakat, baik sipil atau pejabat pemerintah, apabila melihat dan mempunyai bukti yang kuat tentang adanya pelanggaran hukum perkawinan, maka hendaknya mengaju- 
kan permohonan pembatalan perkawinan supaya perkawinan mereka sah menurut agama dan dikuatkan oleh negara. Sehingga terbentuk semangat untuk mengharmonisasikan antara hukum negara dan hukum agama.[a]

\section{DAFTAR PUSTAKA}

Adlani, H.A. Nasri ed., et.al., Himpunan Fatwa Majlis Ulama Indonesia, Jakarta: MUI, 1997.

Basyir, Ahmad Azhar, Hukum Waris Islam, Yogyakarta: UII Press, 2009.

Daud Ali, Muhammad, Hukum Islam dan Peradilan Agama (Kumpulan Tulisan), Jakarta: Rajawali Press, 1997.

, Hukum Islam, Pengantar Ilmu Hukum dan Tata Hukum Islam di Indonesia, Jakarta: Raja Grafindo Persada, 2012. Mimbar Hukum, No. 81993.

Departemen Agama RI, Al-Qur'an danTerjemahnya, Semarang: CV Toha Putra, 1989.

Inpres Nomor 1 Tahun 1991 tentang Kompilasi Hukum Islam

Islamiyati, 2016, "Implikasi Yuridis Putusan Mahkamah Konstitusi No. 68/PUU/XII/2014 terhadap Penyelundupan Hukum Nikah Beda Agama dalam Perspektif Hukum Islam", Tesis, MIH UNDIP, Semarang.

Kepaniteraan Mahkamah Konstitusi Republik Indonesia, Data Dokumen Putusan No. 68/PUU-XII/2014, Jakarta, 2014.

Mun'im A. Sirry (Ed.), Fiqih Lintas Agama; Membangun Masyarakat InklusifPluralis, Jakarta; Paramadina, 2004.

Mardani, Hukum Islam, Pengantar Ilmu Hukum Islam di Indonesia, Yogyakarta: Pustaka Pelajar, 2010.

Mukti Arto, Ahmad, Pembaruan Hukum Islam Melalui Putusan Hakim, Yogyakarta: Pustaka Pelajar, 2015.

Mertokusumo, Sudikno, Penemuan Hukum Sebuah Pengantar, Yogyakarta: Liberty, 1996.

Nancy J. Smith-Hefner, The New Muslim Romance: Changing Patterns of Courtship and Marriage Among Educated Javanese Youth, Journal of Southeast Asian Studies/Volume 36/Issue 03/October 2005, pp 441459, Printed in the United Kingdom, The National University of Singapore Published online: 08 September 2005. 
Islamiyati

Peraturan Mahkamah Konstitusi Nomor 06/PMK/2005 tentang Pedoman Beracara dalam Pengujian Undang-Undang.

Pimpinan Wilayah Muhammadiyah Jawa Tengah, Dokumen Himpunan Putusan Majlis Tarjih Muhammadiyah 22 di Malang Jawa Timur, 1997.

PP Nomor 9 Tahun 1975 tentang Pedoman Pelaksanaan UU Perkawinan.

Rofiq, Ahmad, Hukum Perdata Islam di Indonesia, Jakarta: Raja Grafindo Persada, 2012.

al-Shāțibī, al-Muwāfaqāt fi Uṣūl al-Aḥkām, Jilid II, tt.: Dār al-Fikr, t.th.

Soekanto, Soerjonodan Sri Mamuji, Penelitian Hukum Normatif(Suatu Tinjauan Singkat), Jakarta: Rajawali Press, 1997.

Soekanto, Soerjono, Beberapa Permasalahan Hukum dalam Kerangka Pembangunan di Indonesia, Yogyakarta: UII Press, 1983.

Sudirman Abbas, Ahmad, Sejarah Qawa'id Fiqhiyyah, Jakarta: Pedoman Ilmu Jaya, 2004.

al-Suyūțī, Jalāl al-Dīn, al-Jāmi' al-Șaghīr, Juz II, Bandung: al-Ma'arif, t.th.

UUD NRI 1945 (kaidah dasarnya).

UU Nomor 1 Tahun 1974 tentang Perkawinan.

UU Nomor 3 Tahun 2006 tentang Peradilan Agama.

UU Nomor 24 Tahun 2003 tentang MK.

UU Nomor 11 Tahun 2012 tentang Peraturan Pembentukan UU. 